BIOEDUSAINS: Jurnal Pendidikan Biologi dan Sains

Volume 2, Nomor 2, Desember 2019

e-ISSN : 2598-7453

DOI: https://doi.org/10.31539/bioedusains.v2i2.953

\title{
KEANEKARAGAMAN JENIS KUPU-KUPU FAMILI NYMPHALIDAE DI KAWASAN BUKIT COGONG
}

\author{
Merti Triyanti ${ }^{1}$, Destien Atmi Arisandy ${ }^{2}$ \\ STKIP-PGRI Lubuklinggau ${ }^{1,2}$ \\ Mertitriyanti28@gmail.com ${ }^{1}$
}

\begin{abstract}
ABSTRAK
Penelitian ini bertujuan untuk mengetahui indeks keanekaragaman jenis kupukupu famili nympalidae yang ada di Bukit Cogong kabupaten Musi Rawas. Penelitian ini menggunakan metode eksplorasi dan deskripsi dengan menggunakan teknik menjelajah transek. Stasiun pengamatan ditentukan menjadi 3 stasiun dengan 5 buah transek secara sistematis dengan luas transek 100m X $100 \mathrm{~m}$. Penangkapan menggunakan jaring net, pengidentifikasian dengan melakukan pengamatan ciri-ciri morfologi kupu-kupu family nympalidae. Berdasarkan penelitian, diperoleh data 106 Individu capung dari 12 Spesies kupukupu dari 6 famili nympalidae yaitu Junonia atlites, Ideopsis juventa, junoni orithya, Cupha erymanthis, Micalesis mineus, Junonia almana, Melanitis leda, Danaus genutia, Euploea mulciber, Euploea eunice, Phaedyma columella, dan Doleschallia bisaltide. Komposisi jenis yang paling rendah yaitu Phaedyma columella, dan Doleschallia bisaltide sebesar 1,89\%, sedangkan yang paling tinggi yaitu Junonia atlites sebesar. 33,01\%. Simpulan, Indeks keanekaragaman jenis kupu-kupu famili nympalidae di Bukit Cogong Kabupaten Musi Rawas berkategori sedang dengan nilai sebesar 2,48. Indeks keseragaman pada seluruh stasiun berkategori tinggi, komunitas stabil dan indeks dominansi (C) pada seluruh stasiun berkategori rendah.
\end{abstract}

Kata Kunci: keanekaragaman, kupu-kupu, family nympalidae, bukit cogong

ABSTRACT
This study aims to determine the diversity index of the species of nympalidae
family in the Cusi Hill area of Musi Rawas. This research uses exploration and
description methods using transect roaming techniques. The observation station
was determined to be 3 stations with 5 transects systematically with a transect
area of $100 m$ x $100 m$. Catching using net net, identification by observing the
morphological characteristics of the nympalidae family butterfly. Based on the
study, 106 data obtained from dragonflies from 12 species of butterflies from 6
families of nympalidae, namely Junonia athletes, Ideopsis juventa, Junoni orithya,
Cupha erymanthis, Micalesis mineus, Junonia almana, Melanitis leda, Danaus
genutia, Ideopsis juventa, Junoni orithya, Cupha erymanthis, Micalesis mineus,
Junonia almana, Melanitis leda, Danaus genutia, Euploea mulciber, Euploea
eunhaa, Phupa columella, and Doleschallia bisaltide. The lowest species
composition was Phaedyma columella, and Doleschallia bisaltide by 1.89\%,
while the highest was Junonia athletes by. 33.01\%. Conclusion The diversity
index of the butterfly species of nympalidae family in Bukit Cogong, Musi Rawas
Regency is in the medium category with a value of 2.48. uniformity index at all


stations in the high category, stable community and dominance index $(C)$ in all stations in the low category.

Keywords: diversity, butterflies, family nympalidae, bukit cogong

\section{PENDAHULUAN}

Serangga (insecta) adalah kelompok utama dari hewan berbuku-buku dan merupakan kelompok hewan dengan jumlah terbanyak di dunia. Lebih dari 800.000 jenis serangga sudah di temukan. Serangga dibagi lagi menjadi kelompok-kelompok, diantaranya bangsa capung (Odonata) sebanyak 5.000 jenis, bangsa belalang (Orthoptera) sebanyak 20.000 jenis, bangsa kupu-kupu dan ngengat (lepidoptera) sebanyak 170.000 jenis, bangsa lalat dan kerabatnya (Diptera) sebanyak 120.000 jenis, bangsa kepik (Hemiptera) sebanyak 82.000 jenis, bangsa kumbang (Coleoptera) sebanyak 360.000 jenis, bangsa semut dan lebah (Hymenoptera) sebanyak 110.000 jenis. Serangga merupakan satu-satunya kelompok hewan invertebrata (hewan yang tidak memiliki tulang belakang) yang dapat terbang. Serangga hidup dengan memakan organisme lain, beberapa jenis hidup parasit pada tubuh tumbuhan, hewan, maupun manusia. Jenis lainya hidup secara simbiosis dengan organisme lainnya (Saktyowati, 2011).

Keanekaragaman kupu-kupu di suatu tempat berbeda dengan tempat yang lain, karena keberadaan kupu-kupu di suatu habitat sangat erat kaitannya dengan faktor lingkungan baik faktor abiotik dan biotik seperti intensitas cahaya matahari, temperatur, kelembaban udara dan air, maupun faktor biotik seperti vegetasi dan satwa lain (Lestari, 2015). Kupu-kupu saat ini mulai mengalami pengurangan jumlah bahkan mengalami kepunahan lokal, karena banyaknya alih fungsi hutan, sehingga luas hutan semakin berkurang dengan bertambahnya jumlah manusia membuat lahan hutan beralih menjadi lahan pemukiman dan lahan pertanian (Noor \& Zen, 2015). Selain faktor perubahan ahli fungsi lahan, yang dapat mempengaruhi pengurangan jumlah kupu-kupu yaitu adanya gangguan lingkungan seperti banyaknya kegiatan transportasi, industri, maupun domestik (Azahra, et al, 2016).

Kelimpahan kupu-kupu disuatu tempat tergantung pada habitat yang banyak terdapat tanaman atau tumbuhan inang, penyebaran dari kupu-kupu sangat dipengaruhi oleh ketersedian tumbuhan inang baik sebagai pakan untuk larva dan tumbuhan penghasil nektar (sari bunga) bagi kupu-kupu dewasa. Jika kedua faktor ini tersedia dengan seimbang, maka kupu-kupu dapat melangsungkan hidupnya dari generasi ke generasi (Herlina, 2017).

Berdasarkan dari hasil observasi yang dilakukan Bukit Cogong ditemukan berbagai macam jenis kupu-kupu, diantaranya yaitu family nymphalidae. Tetapi, belum ada data terperinci tentang keanekaragaman jenis kupu-kupu family nympalidae, sehingga perlu dilakukan penelitian tentang keanekaragaman jenis kupu-kupu. Penelitian ini bertujuan untuk mengetahui indeks keanekaragaman 
jenis kupu-kupu famili nympalidae yang ada di Bukit Cogong kabupaten Musi Rawas

\section{METODE PENELITIAN}

Penelitian ini bersifat deskriptif kualitatif, dimana setiap stasiun pengamatan memiliki 5 buah transek dengan luas tiap transek adalah $100 \mathrm{~m}$ x 100 m. Metode deskriptif bertujuan mendeskripsikan sifat atau karakteristik dari suatu peristiwa yang terjadi saat ini (Noor, 2011). Adapun subjek yang akan di jadikan penelitian ini adalah semua jenis-jenis capung yang ditemukan di Bukit Cogong Kabupaten Musi Rawas yang kemudian diamati berdasarkan ciri-ciri morfologinya. penelitian ini menggunakan teknik purposive sampling yaitu peneliti turun langsung menuju ke tempat (area, wilayah, atau lokasi) yang akan diteliti (Sugiyono, 2016).

Berdasarkan data yang telah diperoleh maka akan dilakukan analisis secara deskriptif, yaitu dilihat dari ciri-ciri capung secara morfologi, serta kemudian menjelaskan ciri-ciri yang terdapat pada belalang tersebut. Analisis data meliputi komposisi jenis $(\mathrm{KJ})$, indeks keanekaragaman $\left(\boldsymbol{H}^{\prime}\right)$, indeks keseragaman (E) dan indeks dominansi (Samitra \& Rozi, 2018). Komposisi jenis (KJ) adalah jumlah spesies-i per jumlah seluruh total individu yang tertangkap, dengan rumus sebagai berikut :

$$
\begin{aligned}
& \qquad K J=\frac{n i}{N} \mathbf{X} \mathbf{1 0 0 \%} \\
& \text { dimana: } \\
& \text { KJ= Komposisi jenis (\%) } \\
& \text { ni= jumlah individu spesies-i } \\
& \mathrm{N}=\text { jumlah total individu semua spesies }
\end{aligned}
$$

Sedikit atau banyaknya keanekaragaman spesies dapat dilihat dari indeks keanekaragaman $\left(H^{\prime}\right)$. Keanekaragaman $\left(H^{\prime}\right)$ mempunyai nilai terbesar jika semua individu berasal dari spesies yang berbeda-beda. Indeks keanekaragaman dapat dihitung dengan menggunakan rumus Shannon-Wienner, yaitu:

dimana:

$$
H^{\prime}=-\Sigma \frac{n 1}{N} \times \ln \frac{n 1}{N}
$$

$\mathrm{H}^{\prime}=$ indeks keanekeragaman

$\mathrm{n} 1=$ jumlah individu jenis ke-i

$\mathrm{N}=$ Jumlah individu seluruh jenis

Adapun nilai indeks keanekaragaman dapat dilihat pada tabel 1. di bawah ini, Semakin besar nilai indeks keseragaman (E) menunjukkan kelimpahan yang hampir seragam dan merata antar jenis. 
Tabel 1. Kriteria Indeks Keanekaragaman

\begin{tabular}{ccc}
\hline Indeks Ekologi & Nilai & Kategori \\
\hline \multirow{3}{*}{ Indeks Keanekargaman $\left(\boldsymbol{H}^{\prime}\right)$} & $\boldsymbol{H}^{\prime} \leq 2,0$ & Rendah \\
\cline { 2 - 3 } & $2,0<\boldsymbol{H}^{\prime} \leq 3,0$ & Sedang \\
\cline { 2 - 3 } & $\boldsymbol{H}^{\prime} \geq 3,0$ & Tinggi \\
\hline
\end{tabular}

Nilai indeks keseragaman (E) dapat dihitung menggunakan rumus:

dimana:

$$
\mathrm{E}=\frac{H \prime}{\mathrm{lnS}}
$$

$\mathrm{E}=$ indeks kemerataan jenis

$\mathrm{H}^{\prime}=$ indeks keanekeragaman

$\mathrm{S}=$ Jumlah jenis yang ditemukan

Adapun nilai indeks keseragaman dapat dilihat pada tabel 2. di bawah ini

Tabel 2. Kriteria Indeks Keseragaman

\begin{tabular}{ccc}
\hline Indeks Ekologi & Nilai & Kategori \\
\hline & $\mathrm{E}<0,5$ & $\begin{array}{c}\text { Keseragaman populasi kecil, } \\
\text { komunitas tertekan }\end{array}$ \\
\cline { 2 - 3 } Indeks Keseragaman (E) & $0,50>\mathrm{E} \leq 0,75$ & $\begin{array}{c}\text { Keseragaman populasi sedang, } \\
\text { komunitas labil }\end{array}$ \\
\cline { 2 - 3 } & $0,75<\mathrm{E} \leq 1$ & $\begin{array}{c}\text { Keseragaman populasi tinggi, } \\
\text { komunitas stabil }\end{array}$ \\
\hline
\end{tabular}

Jika nilai indeks keseragaman mendekati 0 dapat diartikan dalam ekosistem/komunitas tersebut terjadi kecendrungan dominansi spesies tertentu, dan jika nilai mendekati 1 maka ekosistem/komunitas berada dalam kondisi relatif stabil dan penyebaran spesies merata. Indeks dominansi digunakan untuk mengetahui dominansi spesies pada suatu daerah. Indeks dominansi dihitung dengan menggunakan rumus sebagai berikut:

dimana:

$$
C=\Sigma(n i / N)^{2}
$$

$\mathrm{C}=$ indeks dominansi

$n i=$ jumlah individu spesies- $\mathrm{i}$

$\mathrm{N}=$ jumlah total individu semua spesies

Adapun kategori indeks dominansi dapat dilihat pada tabel 3.

Tabel 3. Kriteria Indeks Dominansi

\begin{tabular}{ccc}
\hline Indeks Ekologi & Nilai & Kategori \\
\hline \multirow{3}{*}{ Indeks Dominansi $(C)$} & $0,00<\mathrm{C} \leq 0,5$ & Rendah \\
\cline { 2 - 3 } & $0,50>\mathrm{C} \leq 0,75$ & Sedang \\
\cline { 2 - 3 } & $0,75<\mathrm{C} \leq 1$ & Tinggi \\
\hline
\end{tabular}




\section{HASIL PENELITIAN}

Berdasarkan hasil penelitian yang dilakukan di Bukit Cogong Kabupaten Musi Rawas diperoleh 12 spesies kupu-kupu yang berasal dari famili nympalidae. Data dapat dilihat pada tabel 4 berikut ini.

Tabel 4. Spesies capung di Bukit Cogong Kabupaten Musi Rawas

\begin{tabular}{|c|c|c|}
\hline No & Famili & Spesies \\
\hline 1 & \multirow{12}{*}{ Nymphalidae } & Junonia atlites \\
\hline 2 & & Junonia juventa \\
\hline 3 & & Junonia orithya \\
\hline 4 & & Cupha erymanthis \\
\hline 5 & & Micalesis mineus \\
\hline 6 & & Melanitis Leda \\
\hline 7 & & Danaus genutia \\
\hline 8 & & Euploea mulciber \\
\hline 9 & & Euploea eunice \\
\hline 10 & & Junonia almana \\
\hline 11 & & Phaedyna columella \\
\hline 12 & & Doleschallia bisaltide \\
\hline
\end{tabular}

Pada Tabel 4 diketahui bahwa terdapat 12 spesies kupu-kupu famili nympalidae yang berhasil tertangkap. Jumlah individu yang ditemukan di Bukit Cogong sebanyak 106, dari 3 stasiun pengamatan. Data dapat dilihat pada tabel 5.

Tabel 5. Jumlah Spesies capung yang tertangkap disetiap Stasiun penelitian

\begin{tabular}{clcccc}
\hline \multirow{2}{*}{ No } & \multirow{2}{*}{ Nama Spesies } & \multicolumn{3}{c}{ Stasiun Pengamatan } & Jumlah \\
\cline { 3 - 6 } & & Stasiun I & Stasiun II & Stasiun III & \\
\hline 1 & Junonia atlites & 14 & 35 & 9 & 35 \\
\hline 2 & Junonia juventa & 5 & 11 & 2 & 11 \\
\hline 3 & Junonia orithya & 7 & 15 & 5 & 15 \\
\hline 4 & Cupha erymanthis & 4 & 9 & 0 & 9 \\
\hline 5 & Micalesis mineus & 3 & 5 & 2 & 5 \\
\hline 6 & Melanitis Leda & 2 & 7 & 1 & 7 \\
\hline 7 & Danaus genutia & 1 & 4 & 2 & 4 \\
\hline 8 & Euploea mulciber & 1 & 3 & 1 & 3 \\
\hline 9 & Euploea eunice & 2 & 5 & 2 & 8 \\
\hline 10 & Junonia almana & 2 & 8 & 0 & 2 \\
\hline 11 & Phaedyna columella & 1 & 2 & 1 & 2 \\
\hline 12 & Doleschallia bisaltide & 1 & 2 & 25 & 106 \\
\hline Jumlah & & 43 & 38 & & 2 \\
\hline & & & 5 & 2 & 2 \\
\hline
\end{tabular}


Berdasarkan tabel diatas, diketahui bahwa, jumlah spesies paling banyak ditemukan di stasiun I. Sedangkan stasiun III adalah stasiun dengan jumlah spesies paling sedikit. Sedangkan, berdasarkan spesies, stasiun I merupakan stasiun dengan spesies paling banyak yaitu 12 spesies dan stasiun II dan III merupakan stasiun dengan spesies paling sedikit yaitu 9 spesies. Pada stasiun I, II dan III spesies Junonia atlites memiliki jumlah paling banyak yaitu 14, 35, dan 9 .

Komposisi jenis merupakan suatu susunan dan jumlah jenis kupu-kupu famili nympalidae yang tertangkap di Bukit Cogong Kabupaten Musi Rawas. Komposisi jenis jenis kupu-kupu famili nympalidae yang tertangkap di dapat dilihat pada tabel 6 dibawah ini.

Tabel 6. Nilai Komposisi Jenis

\begin{tabular}{clc}
\hline No & \multicolumn{1}{c}{ Spesies } & Komposisi Jenis (\%) \\
\hline 1. & Junonia atlites & 33,01887 \\
\hline 2. & Junonia juventa & 10,37736 \\
\hline 3. & Junonia orithya & 14,15094 \\
\hline 4. & Cupha erymanthis & 8,490566 \\
\hline 5. & Micalesis mineus & 4,716981 \\
\hline 6. & Melanitis Leda & 6,603774 \\
\hline 7. & Danaus genutia & 3,773585 \\
\hline 8. & Euploea mulciber & 2,830189 \\
\hline 9. & Euploea eunice & 4,716981 \\
\hline 10 & Junonia almana & 7,54717 \\
\hline 11 & Phaedyna columella & 1,886792 \\
\hline 12 & Doleschallia bisaltide & 1,886792 \\
\hline
\end{tabular}

Berdasarkan tabel 6 dapat disimpulkan bahwa komposisi jenis kupu-kupu famili nympalidae di Bukit Cogong Kabupaten Musi Rawas yang paling tertinggi yaitu pada spesies Junonia atlites dengan komposisi sebesar 33,01 \%. famili yang paling banyak ditemukan adalah famili nymphalidae dengan jumlah 43 spesies. Pada famili nymphalidae banyak ditemukan jenis Junonia atlites dan yang paling sedikit ditemukan adalah famili papilionidae. Famili nymphalidae memiliki ciri yaitu tubuh berukuran kecil hingga sedang, dan memiliki pola sayap yang bervariasi, serta dari anggota ini umumnya memiliki warna coklat, orange, kuning, dan hitam (Lestari, 2018). Indeks keanekaragaman merupakan salah satu dari bagian struktur komunitas kupu-kupu, dimana indeks keanekaragaman digunakan untuk melihat tingkat keanekaragaman jenis kupu-kupu famili nympalidae di bukit Cogong Kabupaten Musi Rawas. Indeks kanekaragaman jenis kupu-kupu famili nympalidae di Bukit Cogong Kabupaten Musi Rawas dapat dilihat pada tabel 7

Tabel 7. Nilai Indeks Keanekaragaman

\begin{tabular}{cccc}
\hline No. & Stasiun & Nilai Indeks Keanekaragaman $\left(\mathbf{H}^{\prime}\right)$ & Kategori \\
\hline 1. & I & 2,48 & Sedang \\
\hline 2. & II & 2,19 & Sedang \\
\hline 3. & III & 2,19 & Sedang \\
\hline
\end{tabular}


Berdasarkan tabel 7 dapat disimpulkan bahwa hasil analisis indeks keanekaragaman $\left(\mathrm{H}^{\prime}\right)$ pada jenis kupu-kupu famili nympalidae di bukit cogong Kabupaten Musi Rawas menunjukan nilai sebesar 2,48 pada stasiun I, kemudian pada stasiun II sebesar 2,19 dan pada stasiun III sebesar 2,19 maka ketiga stasiun tersebut tergolong dalam ketegori sedang. Indeks Keanekaragaman ( $\left.H^{\prime}\right)$ yang berfungsi untuk memperlihatkan seberapa melimpah tingkat keanekaragaman spesies pada masing-masing stasiun. Hal ini menunjukkan bahwa keadaan jenis kupu-kupu famili nympalidae yang ditemukan di Bukit Cogong memiliki produktivitas sedang, sehingga keanekaragamannya dikategoriakan dalam keadaan seimbang. Seperti yang dikemukakan oleh Indriyanto (2012), keanekaragaman jenis suatu komunitas dikatakan tinggi jika komunitas itu disusun oleh banyak spesies. Sebaliknya suatu komunitas dikatakan memiliki keanekaragaman spesies yang rendah jika komunitas itu disusun oleh sedikit spesies dan jika hanya sedikit spesies yang dominan.

Indeks keseragaman merupakan suatu indeks yang digunakan untuk melihat beberapa jenis kupu-kupu famili nympalidae di bukit cogong kabupaten Musi Rawas. Indeks keseragaman jenis kupu-kupu famili nympalidae di bukit cogong kabupaten Musi Rawas dapat dilihat pada tabel 8 di bawah ini.

Tabel 8. Nilai Indeks Keseragaman

\begin{tabular}{cccc}
\hline No. & Stasiun & Nilai Indeks Keseragaman $(\mathbf{E})$ & Kategori \\
\hline 1. & I & 0,84 & Tinggi \\
\hline 2. & II & 0,90 & Tinggi \\
\hline 3. & III & 0,85 & Tinggi \\
\hline
\end{tabular}

Berdasarkan tabel 8 dapat disimpulkan bahwa hasil analisis indeks keseragaman pada jenis kupu-kupu famili nympalidae di Bukit Cogong Kabupaten Musi Rawas menunjukan nilai sebesar 0,84 pada stasiun I kemudian pada stasiun II sebesar 0,90 dan pada stasiun III sebesar 0,85, maka ketiga stasiun tersebut tergolong kedalam kategori keseragaman populasi tinggi. Dengan demikian, dari ketiga stasiun tersebut mempunyai keseragaman populasi yang tinggi dan komunitasnya stabil. Kriteria nilai keseragaman jenis belalang yaitu nilai E mendekati 1 maka penyebaran individu antar jenis relatif sama (Sagala, et al. 2014).

Indeks dominansi merupakan suatu indeks yang digunakan untuk memperoleh informasi mengenai jenis kupu-kupu famili nympalidae di bukit cogong kabupaten Musi Rawas yang mendominansi pada suatu komunitas yang di temukan. Indeks dominansi jenis kupu-kupu famili nympalidae di Bukit Cogong kabupaten Musi Rawas dapat dilihat pada tabel 9 di bawah ini.

Tabel 9. Nilai Indeks Dominansi

\begin{tabular}{cccc}
\hline No. & Stasiun & Nilai Indeks Dominansi (C) & Kategori \\
\hline 1. & I & 0,17 & Rendah \\
\hline 2. & II & 0,16 & Rendah \\
\hline 3. & III & 0,20 & Rendah \\
\hline
\end{tabular}


Berdasarkan tabel 9 dapat disimpulkan bahwa hasil analisis indeks dominansi pada jenis kupu-kupu famili nympalidae di Bukit Cogong kabupaten Musi Rawas, pada stasiun I yaitu sebesar 0,17 sedangkan pada stasiun II sebesar 0,16 dan pada stasiun III yaitu sebesar 0,20. Maka nilai indeks dominansi dari ketiga stasiun tersebut memiliki nilai sama-sama rendah. Hal ini berkaitan dengan indeks keanekaragaman yang juga berkategori rendah. Indriyanto (2012) mengemukakan bahwa suatu komunitas dikatakan memiliki keanekaragaman spesies yang rendah jika komunitas itu disusun oleh sedikit spesies dan jika hanya sedikit spesies yang dominan. Hal ini sesuai dengan hasil penelitian yang hanya memiliki 1 spesies dominan yang ditemukan pada 3 stasiun.

\section{PEMBAHASAN}

Berdasarkan hasil penelitian yang telah dilakukan di Bukit Cogong kabupaten Musi Rawas dengan menggunakan metode jelajah ditemukan 12 jenis dengan jumlah 106 individu. Pada famili nymphalidae banyak ditemukan jenis Junonia atlites yaitu Junonia atlites. Famili nymphalidae memiliki ciri yaitu tubuh berukuran kecil hingga sedang, dan memiliki pola sayap yang bervariasi, serta dari anggota ini umumnya memiliki warna coklat, orange, kuning, dan hitam (Lestari, 2018). Famili nymphalidae banyak ditemukan di semak-semak dan di rerumputan karena semak-semak dan rerumputan merupakan tumbuhan inang, famili nymphalidae adalah famili yang memiliki kemampuan bertahan hidup yang tinggi pada berbagai jenis habitat karena bersifat polifag yaitu memakan banyak jenis tumbuhan (Gosal, et.al, 2015).

Keberadaan kupu-kupu nymphalidae yang sangat banyak merupakan hasil dari banyaknya ketersediaan sumber pakan dihabitatnya (Rahayu, 2012). Famili nymphalidae yang ditemukan di Bukit Cogong memiliki tumbuhan pakan dan tumbuhan inang yang cukup sehingga famili nymphalidae ini banyak yang hidup di kawasan Bukit Cogong.

Menurut Lamatoa, et al, (2013) famili nymphalidae banyak ditemukan karena famili ini merupakan famili terbesar jumlahnya dalam ordo lepidoptera. Famili nymphalidae umumnya mempunyai penyebaran yang luas, karena menyukai tempat yang terang, daerah kebun, dan hutan. Banyaknya kupu-kupu famili nymphalidae yang ditemukan di kawasan Bukit Cogong karena adanya ketersediaan makanan dan didukung dengan faktor abiotik yang mendukung untuk berlangsungnya kehidupan kupu-kupu famili nymphlidae. Adapun famili nymphalidae sangat menyukai tempat yang terang, daerah kebun, dan hutan. Jadi famili nymphalidae merupakan famili yang memiliki persebaran yang luas karena famili nymphalidae hidup bersifat polifag yaitu memakan banyak jenis tumbuhan lebih dari satu. Bukit Cogong merupakan tempat yang cocok untuk kehidupan kupu-kupu famili nymphalidae karena kondisi lingkungan di Bukit Cogong mendukung untuk keberlangsungan hidup pada famili nymphalidae. Famili nymphalidae ini merupakan famili terbesar dalam persebarannya. 
Jenis kupu-kupu dalam suatu komunitas sangat tergantung oleh tumbuhan pakan dan faktor lingkungan seperti suhu udara, kelembapan tanah, dan intensitas cahaya, keadaan lingkungan yang disukai kupu-kupu yaitu intensitas cahaya matahari yang tinggi dan kelembapan yang tinggi. Jika suhu di suatu habitat tinggi maka harus didukung kelembapan yang tinggi pula (Dewi, 2016).

Keanekragaman kupu-kupu sagat berpengaruh terhadap perubahan lingkungan, karena kehidupan dan keberadaan kupu-kupu sangat bergantung pada sumber makanan, suhu, musim, dan kelembapan. Kupu-kupu dapat bertahan hidup jika sumber makanan di suatu habitat banyak atau melimpah. Menurut Wardhania, et al, (2017) keanekaragaman kupu-kupu di suatu tempat berbeda dengan yang lain karena keberadaan kupu-kupu di suatu habitat sangat erat kaitannya dengan faktor lingkungan seperti intensitas cahaya matahari, kelembapan dengan kisaran 60-94\%, suhu dengan kisaran $15-45^{\circ} \mathrm{C}$. Jadi kondisi lingkungan dan ketersediaan makanan sangat berpengaruh terhadap kehidupan dan keanekaragaman kupu-kupu di suatu habitat. Kupu-kupu sangat berpengaruh terhadap perubahan lingkungan, karena kehidupan dan keberadaan kupu-kupu sangat bergantung pada sumber makanan, suhu, musim, dan kelembapan. Kupukupu dapat bertahan hidup jika sumber makanan di suatu habitat banyak atau melimpah.

\section{SIMPULAN}

Berdasarkan Hasil penelitian dapat disimpulkan bahwa penelitian yang telah dilaksanakan di kawasan Bukit Cogong Kabupaten Musi Rawas yang ditemukan sebanyak 12 spesies dan 106 individu. Komposisi jenis yang paling rendah yaitu Phaedyma columella, dan Doleschallia bisaltide, sedangkan yang paling tinggi yaitu Junonia atlites Indeks keanekaragaman jenis kupu-kupu famili nympalidae di Bukit Cogong Kabupaten Musi Rawas berkategori sedang. indeks keseragaman pada seluruh stasiun berkategori tinggi, komunitas stabil dan indeks dominansi (C) pada seluruh stasiun berkategori rendah.

\section{DAFTAR PUSTAKA}

Dewi, B., Hamidah, A., \& Suburian, J. (2016). Keanekaragaman dan Kelimpahan Jenis Kupu-kupu (Lepidoptera:Rhopalocera) disekitar Kampus Pinang Masak. Jurnal biospesies 2(9); 32-38.

Gossal, M.L. Memah Ventje, \& Rimbing, J. (2016). Keanekaragaman dan Perbedaan Jenis Kupu-kupu (Ordo:Lepidoptera) Berdasarkan Topografi Pada Tiga Lokasi Hutan di Sulawesi Utara. Jurnal Bioslogos 6 (2); 43-50.

Herlina, S. (2017). Kelimpahan Kupu-kupu Nymphalidae Di Kawasan Air Terjun Parangloe Kabupaten Gowa. Skripsi Fakultas Sains dan Teknologi Uin Alauudin Makassar. 19-23.

Indriyanto, (2006). Ekologi Hutan. Jakarta: PT. Bumi Aksara.

Lamatoa, CD. (2013). Populasi Kupu-kupu (Lepidoptera) di Pulau Manthg Sulawesi Utara. Jurnal Ilmiah Sains 13 (1); 53-56. 
Lestari C.V. (2018). Keanekaragaman Jenis Kupu-kupu Famili Nymphalidae dan Pieridae dikawasan Cirengganis dan Padang Rumput Cikamal Cagar Alam Pananjung Pangandaran. Jurnal Agrikultura 29 (1); 1-8.

Lestari F.D., Putri, R.D.A., Ridwan, M., \& Purwaningsih, A.D. (2015). Keanekaragaman Kupu-kupu (Insekta:Lepidoptera) di Wana Wisata Alas Bromo, BKPH Lawu Utara Karang Anyar Jawa Tengah. Paper dipresentasikan oleh Prosem Nas Masy Biodiv Indon.

Noor, R. \& Zen, S. (2015). Studi Keanekaragaman Kupu-kupu di Bantaran Sungai Batanghari Kota Metro Sebagai Sumber Belajar Biologi Materi Keanekaragaman. Jurnal Pendidikan Biologi 6 (1); 71-78.

Rahayu, S.E. \& Baskuriadi A. (2012). Kelimpahan dan Keanekaragaman Spesies Kupu-kupu (Lepidoptera:Rhopalocera) pada Berbagai Tipe Habitat di Hutan dan Kota Muhamad Sabki Kota Jambi. Jurnal Biospesies 2 (5); 4048.

Sagala, M. M. (2014). Distribusi Logam Berat di Perairan Natuna Distribution of Heavy Metals in Natuna Coastal Waters. Jurnal Ilmu dan Teknologi Kelautan Tropis, 6(2); 297-310.

Saktyowati, D. O. (2011). Keunikan Dunia Serangga. Jakarta:PT. Wadah Ilmu.

Samitra, D. \& Rozi, Z., F. (2018). Keanekaragaman Ikan di Sungai Kelingi Kota Lubuklinggau. Jurnal Biota, 4 (1); 1-6.

Sugiyono. (2016). Metode Penelitian Kuantitatif, Kualitatif, dan R\&D. Bandung: Alfabeta cv.

Wardhania. (2017). Keragaman Kupu-kupu di Taman Wisata Alam Baning Sintang. Jurnal Edumedia 1 (1); 28-32. 